\title{
Okul Öncesi Öğretmenlerinin Uzaktan Eğitim Sürecinde Uyguladıkları Aile Katılım Çalışmalarının İncelenmesi
}

\author{
DOI: $10.26466 /$ opus. 827530
}

*

\section{Serhat Gündoğdu *}

* Dr. Öğr. Üyesi, Nevşehir Hacı Bektaş Veli Üniversitesi

E-Posta: gundogduserhat50@gmail.com ORCID: 0000-0001-6841-8890

\section{Öz}

Okul öncesi öğretmenlerinin uzaktan eğitim sürecinde uyguladıkları aile katılım çalışmalarını belirlemek amacıyla yapılan bu çalışma nitel araştırma yöntemiyle gerçekleştirilmiştir. Çalışma grubunu basit tesadüfi örnekleme yöntemle belirlenen 35 okul öncesi öğretmeni oluşturmaktadır. Çalışmanın verileri yarı yapılandırılmış sorulardan oluşan görüşme formu ile toplanmıştır. Veriler nitel araştırma veri analiz yöntemlerinden içerik analizi ile araştırmacı tarafindan analiz edilmiştir. Araştırmanın sonucunda uzaktan eğitim sürecinde okul öncesi öğretmenlerinin aile katılım çalışmalarında farklılıklar olduğu ortaya çıkmıştır. Bu farklılaşma daha çok olumlu yönde olmuştur. Ailelerin yaklaşık yarısının uzaktan eğitim sürecine aktif katıldıkları ve bunların büyük çoğunluğunu annelerin oluşturduğu ortaya çıkmıştır. Babaların çalışıyor olması ve annelerin ev hanımı olması bu duruma neden olmuştur. Öğretmenler ailelerle iletişim kanalı olarak en çok whatsapp mesaj uygulamasını ĕ̆itim öğretim faaliyetleri için kullanmışlardır. Öğretmenler uzaktan eğitim sürecinde ailelerle, çocuklarla ve sistemsel yapı ile ilgili sorunlar yaşamışlar. Uzaktan eğitim sürecinde aile katılımının arttırılması ve verimli hale getirilmesi için öğretmenler; ailelere, çocuklara ve sistemsel yapıya ilişkin önerilerde bulunmuşlardir.

Anahtar Kelimeler: Okul öncesi eğitim, uzaktan eğitim, aile katılımı 
ISSN: 2528-9527

E-ISSN : 2528-9535

Yıl Year: 11

Cilt Volume: 17

Sayı Issue: 35

Mart March 2021

Makalenin Geliș Tarihi Received Date. 17/11/2020

Makalenin Kabul Tarihi Accepted Date. 29/03/2021

\title{
Investigation Of The Family Participation Activities Which Pre-School Teachers Apply In The Distance Education Process
}

\begin{abstract}
This study was carried out with the qualitative research method in order to determine the family participation studies applied by preschool teachers in the distance education process. The study group consists of 35 preschool teachers determined by simple random sampling method. The data of the study were collected with an interview form consisting of semi-structured questions. The data were analyzed by the researcher with content analysis, one of the qualitative research data analysis methods. As a result of the study, it was revealed that there are differences in the family participation studies of preschool teachers in the distance education process. This differentiation has been more positive. It has been revealed that nearly half of the families actively participate in the distance education process, and most of them are mothers. Fathers working and mothers being housewives caused this situation. Teachers mostly used the Whatsapp message application for educational activities as a communication channel with families. Teachers had problems with families, children and systemic structure during the distance education process. In order to increase family participation in the distance education process and to make it efficient, teachers; they made suggestions to families, children and systematic structure.
\end{abstract}

Keywords: Preschool education, distance education, family participation 


\section{Giriş}

2019 yılının aralık ayında Çin'in Wuhan kentinde Koronavirüs (COVID-19) olarak adlandırılan yeni bir virüs ortaya çıktı. İlk zamanlarda birçok insan, virüsün ortaya çıtığı alanla sınırlı kalacağını ve çok az sonuçları olacağını düşünüyordu. Zamanla bu virüsün hizlı ve kapsamlı bir şekilde yayılma potansiyeline sahip olduğu ortaya çıktı. Koronavirüs dünyanın neredeyse tamamına kısa sürede yayılım gösterdi ve salgın haline geldi. Türkiye'de de ilk Koronavirüs vakası 11 Mart 2019 tarihinde ortaya çıktı. Salgın doğrudan ve dolaylı olarak herkesi etkiledi ve hayatın her alanında birçok değişikliğe neden oldu. Salgın sağlık sistemi başta olmak üzere ekonomi, sosyal ve eğitim sistemlerini de etkiledi ve bir tehdit oluşturdu.

Türkiye'de salgının olumsuz etkilerinin hissedildiği sistemlerden biri de eğitim sistemiydi. Salgının yayılmasını önlemek için Türkiye'de 16 Mart 2020 'de okullar iki hafta süreyle kapatıldı. İlerleyen günlerde Koronavirüs vakalarındaki artışla birlikte okulların kapanma süreci uzatıldı. Bu durum eğitimin uzaktan yapılmasını zorunlu kıldı. Türkiye, kısa bir hazırlığın ardından 23 Mart 2020 tarihinde okul öncesinden liseye kadar tüm eğitim seviyeleri için uzaktan eğitim sürecini başlattı.

Uzaktan eğitim, öğrenci ve öğretmen arasında fiziksel uzaklığın olduğu ve öğrencinin öğretmenle iletişim kurmak ve eğitim materyallerine erişmek için iletişim teknolojilerini kullandığı eğitim faaliyetleridir (Balıkçığlu, Çınar Öz ve Işın, 2019, s. 462). Uzaktan eğitim, fiziki mesafeyle ilgili sorunların yanı sıra derslere yüz yüze katılımı engelleyen birçok nedenden dolayı da ele alınmaktadır. Küresel, sosyal, ekonomik, teknolojik, bilimsel ve bilginin yayılma hızındaki gelişmeler uzaktan eğitim ihtiyacını doğurmaktadır (Foti, 2020, s. 19). Uzaktan eğitim, geleneksel yöntemlerden farklı olarak salgın döneminde de okulların kapanmasının ardından eğitim ve öğretim sürecini devam ettirmek için en uygun yol olarak görüldü.

Türkiye'de uzaktan eğitim, devlet kanalıyla 'Eğitim Bilişim Ağı Televizyonu (EBA TV)' ve 'Eğitim Bilişim Ağı (EBA)' adlı çevrimiçi eğitim platformu ile gerçekleşmektedir. EBA TV'de okul öncesi eğitime yönelik kanal bulunmaz iken EBA çevrimiçi eğitim platformunda okul öncesi eğitim içerikleri bulunmaktadır. Milli Eğitim Bakanlığı tarafından geliştirilen EBA 2011-2012 eğitim-öğretim yılında kullanılmaya başlamıştır. Öğretmenler programa dayalı videolar, e-kitaplar, sınavlar, çalışma kağıtları, belgeseller, 
çizgi filmler gibi eğitim materyallerini okul öncesi eğitimden lise seviyesine kadar sistem üzerinden paylaşmaktadırlar (Özer, 2020, s.1126). Öğretmenler uzaktan eğitim için ayrıca 'Zoom' ve 'Discord' gibi diğer platformları ve farklı kanalları da kullanmaktadırlar.

Salgin döneminde uzaktan eğitim, okul öncesi eğitim için de uygulanan bir yöntem olarak ortaya çıktı. Brown, Riele, Shelley ve Woodroffe (2020)'e göre eğitimin uzaktan da olsa sürekliliğinin sağlanması çocukların yararına olmaktadır. Aksi halde okul öncesi dönem çocukları için eğitimsel çıtıları, beslenmeleri, fiziksel hareketleri, sosyal ve duygusal sağlıkları okulla bağlantısının kesilmesinden etkilenmektedir. Okul öncesi dönem çocuklarının uzun süre okuldan uzak kalmaları ve eğitimin uzaktan olması kaliteli bir okul öncesi eğitimin gerçekleşmesinde bir problem olarak görülmektedir. Çünkü iyi tasarlanmış bir okul öncesi eğitim ortamı kaliteli bir eğitim için önemlidir. Okullar; materyal kaynakları, bilgisayarlar ve internet erişimi, diğer bilgi kaynakları, öğrenmeye uygun fiziksel alan ve etkileşimli ortam sağlama açısından en elverişli ortamlardır.

Sooter (2013)'e göre çocukların bağımsızlıklarında yaş önemli bir faktördür ve okul öncesi dönem çocukları bağımsızlıklarını geliştirme sürecindedirler. Çocuklar büyüdükçe düşünceleri ve eylemleri olgunlaşmakta, ev ve okul etkinliklerinde daha bağımsız olmaktadırlar. Ayrıca günümüzde uzaktan eğitim teknoloji kullanmayı gerektirmektedir. Okul öncesi dönem çocuklarının teknolojik öğrenme araçlarıyla sınırlı deneyimi olduğu ve bağımsız olarak bu araçları kullanmalarının yeterli düzeyde olmadığ 1 belirgindir (Fedynich 2014 ve Wedenoja 2020'den aktaran: Kim, 2020, s. 148). Çocuklar ayrıca kendi kendini yönetme, motivasyon ve eğitimcinin yardımı olmadan eğitim materyalini anlama konusunda sorunlarla karşılaşma eğilimindedirler (Stevens ve Borup, 2015'den aktaran: Novianti ve Garzia, 2020, s. 119). Dolayısıyla okul öncesi dönem çocuklarının bağımsız olarak uzaktan eğitim sürecine katılmaları zor olmaktadır. Bu yüzden normal eğitimde olduğu gibi uzaktan eğitim sürecinde de aile katılımı kaçınılmaz olarak gün yüzüne çıkmaktadır. Aileler, özellikle uzaktan eğitim sürecinde ev ile okul arasında uyum sağlamak ve uzaktan eğitimin olumsuzluklarını en aza indirmek için kritik öneme sahiptir.

Okul öncesi dönemde eğitimin etkili ve başarılı olmasında ailelerin çocuklarının eğitimine katılımı önemli biri unsur olarak görülmektedir (Hornby ve Lafaele, 2011, s.37). Çocuklar zamanlarının büyük bir bölümünü 
aileleriyle geçirirler. Dolayısıyla aileler çocukların potansiyelini keşfetmelerinde, kendini gerçekleştirmelerinde ve başarılarını arttırmalarında önemli bir role sahiptirler. Bu yüzden okul öncesi dönem çocuğunun eğitiminde okul ve aile eşit sorumluluğa sahiptir (MEB, 2013, s. 10). Ailelerin çocukların eğitiminde sorumluluk almaları, rol oynamaları ve çocukların eğitimine katkı sağlamaları olarak tanımlanan aile katılımı (Ural, 2010'den aktaran Aktaş Arnas, 2013, s. 55) çocuğun kazanımlarını da artırmaktadır. Aile katılımı, çocukların; gelişimlerini desteklemekte (Del Bono, Francesconi, Kelly ve Sacker, 2016, s. F101) akademik başarılarını arttırmakta (Çelenk, 2003, s. 32; Wilder, 2014, s. 392), özgüvenlerini arttırmakta (Yaşar Ekici, 2017, s. 558), olumlu tutum ve davranışlar geliştirmesini sağlamakta (Nakamura, 2000'den aktaran: Günay Bilaloğlu, 2014, s. 17), sosyalleşmelerini sağlamakta (Ekinci Vural, 2006, s. 104), öğretmenleri, aileleri ve akranlarıyla daha iyi iletişim kurmalarını sağlamaktadır (Günay Bilaloğlu, 2014, s. 17). Okul öncesi eğitimde aile katılım çalışmalarında öğretmenlere büyük sorumluluk düşmektedir. Öğretmenlerin olumlu tutum ve davranışları aktif aile katıl1mının sağlanmasında çok önemli bir rol oynamaktadır. Öğretmenlerin aile katılımına verdikleri önem katılımın kalitesini de etkilemektedir (Koçyiğit, 2015, s. 142).

Okul öncesi eğitimde aile katılım çalışmaları; aile eğitim etkinlikleri, aile iletişim etkinlikleri, ailelerin eğitim etkinliklerine katılımı, ev ziyaretleri ve ailenin karar alma süreçlerine katılımı olarak beş boyutta gerçekleşmektedir (Günay Bilaloğlu, 2014, s.29). Uzaktan eğitim sürecinde aile eğitim etkinlikleri, ev ziyaretleri ve ailenin karar alma süreçlerine katılımı üzerinde daha az durulan aile katılım çalışmaları olmaktadır. Bunun yanında aile iletişim etkinlikleri ve ailelerin eğitim etkinliklerine katılımı uzaktan eğitim sürecinde de devam eden aile katılım çalışmaları olmuştur. Türkiye'de okul öncesi eğitimde aile katılımı konusunda birçok çalışma bulunurken yeni karşılaşılan COVID sonrası uzaktan eğitim süreçlerinde aile katılım çalışmalarının incelenmesi gerekmektedir. Bu çalışma okul öncesi öğretmenlerinin uzaktan eğitim sürecinde uyguladıkları aile katılım çalışmalarını incelemeyi amaçlamaktadır. Bu çerçevede aşağıdaki sorulara cevap aranacaktır:

1. Okul öncesi öğretmenlerinin gerçekleştirdikleri aile katılım çalışmaları yüz yüze eğitim ile uzaktan eğitim sürecinde farklılaşmakta mıdır?

2. Ailelerin uzaktan eğitim sürecine katılma durumları nasıldır? 
3. Okul öncesi öğretmenlerinin uzaktan eğitim sürecinde aileler ile iletişim kurdukları kanallar nelerdir?

4. Okul öncesi öğretmenleri hangi amaçlar için aileler ile etkileşime geçmişlerdir?

5. Uzaktan eğitim sürecine katılan aile bireyleri ve katılım gerekçeleri nelerdir?

6. Okul öncesi öğretmenlerinin uzaktan eğitim sürecinde aile katılım çalışmalarında karşılaştıkları sorunlar nelerdir?

7. Uzaktan eğitim sürecinde aile katılımının arttırılması ve verimli hale getirilmesi için okul öncesi öğretmenlerinin önerileri nelerdir?

\section{Yöntem}

\section{Araştırma Modeli}

Okul öncesi öğretmenlerinin uzaktan eğitim sürecinde uyguladıkları aile katılım çalışmalarını incelemeyi amaçlayan bu çalışma nitel araştırma yaklaşımlarından durum çalışması ile desenlenmiştir. Merriam (2013, s. 40) durum çalışmalarını sınırlı bir sistemin derinlemesine betimlenmesi ve incelenmesi olarak ifade etmiştir. Durum çalısmasının belirgin özelliği nasıl ve niçin sorularını temele alarak bir olgu ya da olayın derinlemesine incelenmesidir. Bu çalışmada da okul öncesi öğretmenlerinin uzaktan eğitim sürecinde aile katılım çalışmalarını nasıl uyguladıkları araştırılmıştır.

\section{Çalışma grubu}

Araştırmanın çalışma grubunu, Nevşehir ilindeki anaokulu ve ilkokulların anasınıflarında görev yapan 35 okul öncesi öğretmeni oluşturmuştur. Kat1lımclar amaçlı rastgele örneklem yöntemi ile seçilmiştir. Amaçlı rastgele örneklem sistematik ve rastgele seçilen durum örneklerinin araştırmanın amacı doğrultusunda amaçlı bir şekilde tasnif edilmesidir (Marshall ve Rossman, 2014'den aktaran: Baltacı, 2018, s. 258). Katılımcıların kişisel bilgileri tablo 1'de verilmiştir. 


\begin{tabular}{|c|c|}
\hline Cinsiyet & $\mathbf{N}$ \\
\hline Kadın & 35 \\
\hline Erkek & 0 \\
\hline Yaş & $\mathbf{N}$ \\
\hline $27-31$ arasi & 4 \\
\hline $32-36$ arası & 17 \\
\hline $37-41$ aras1 & 9 \\
\hline 42 ve üzeri & 5 \\
\hline Mesleki Deneyim & $\mathbf{N}$ \\
\hline $1-5 \mathrm{yll}$ & 1 \\
\hline $6-10$ yil & 9 \\
\hline $11-15$ yil & 20 \\
\hline $16-20$ yil & 2 \\
\hline 21 yıl ve üzeri & 3 \\
\hline Çalışılan Kurum & $\mathbf{N}$ \\
\hline Anaokulu & 20 \\
\hline İlkokul & 15 \\
\hline Çalışılan Kurumun Yerleşim Bilgisi & $\mathbf{N}$ \\
\hline Şehir Merkezi & 29 \\
\hline İlçe Merkezi & 4 \\
\hline Köy/Kasaba & 2 \\
\hline Çalışılan Grup & $\mathbf{N}$ \\
\hline 3-4 yaş & 4 \\
\hline $4-5$ yaş & 8 \\
\hline 5-6 yaş & 23 \\
\hline
\end{tabular}

\section{Veri Toplama Araçlarn ve Verilerin Toplanma Süreci}

Veriler yarı yapılandırılmış görüşme soruları ile hazırlanan görüşme formu ile toplanmıştır. Görüşme formunda çalışmanın amacı ve içeriği hakkında bilgiler verilmiştir. Görüşme formu katılımcıların kişisel bilgileri ve okul öncesi öğretmenlerinin uzaktan eğitim sürecinde uyguladıkları aile katılım çalışmaları ile ilgili açı uçlu sorulardan oluşmaktadır. Görüşme soruları literatür taraması yapılarak (Aktaş Arnas, 2013; Avcı, 2013; Aydoğan, 2010) ve uzman görüşleri alınarak araştırmacı tarafından hazırlanmıştır. Gerekli resmi izinler alındıktan sonra Nevşehir il merkezinde bulunan bağımsız anaokulu yöneticileri ile yüz yüze iletişime geçilerek hem kendi okullarında çalışan hem de tanıdıkları okul öncesi öğretmenlerine formun gönderilmesi sağlanmıştır. Veriler 01 Haziran 2020 ile 29 Temmuz 2020 arasında toplanmiştır. 


\section{Verilerin Analizi}

Görüşme kayıtlarından elde edilen veriler içerik analizi yöntemi ile analiz edilmiştir. İçerik analizi, toplanan verileri açıklayabilecek kavramlara ve ilişkilere ulaşmayı amaçlamaktadır. İçerik analiz süreci verilerin kodlanmasını ve kategorilerin oluşturulmasını kapsar (Yıldırım ve Şimşek, 2005: 227). İçerik analizinde tümevarımsal yaklaşım uygulanarak kodlar doğrudan verilerden üretilmiş ve kategoriler oluşturulmuştur. Aynı kategori altında anlam bakımından ilişkili olan veriler toplanmıştır. Kodlar arasındaki ilişkiler incelenerek benzerlik ve farklılıklar ortaya çıkarılmış ve araştırma bulgularını oluşturacak kategoriler oluşturulmuştur. Elde edilen kategoriler rapor edilirken frekans hesaplamasından yararlanılmış ve kategorilerin mümkün olduğunca tanımlayıcı olmasına dikkat edilmiştir.

\section{Geçerlilik, Güvenilirlik ve Etik}

Bu çalışmada geçerlilik ve güvenirlilik ile ilgili çeşitli önlemler alınmıştır. Veri analiz sürecinde kategori oluşturma sürecinde alan uzman doktora derecesine sahip bir akademisyen ile bilgi alışverişinde bulunulmuştur. Nakledilebilirliği artırmak için bulgularda katılımcların kendi ifadelerinden alıntılara yer verilmiştir. Amaçlı rastgele örneklem yöntemi ile örneklem seçilerek inanırlılık sağlanmıştır. Etik kurallar çerçevesinde veri analizinde sayılar kullanılarak katılımcılara 1-35 arası sayı verilmiştir. Alıntılarda bu sayılar kullanılmıştır. Nevşehir Hacı Bektaş Veli Üniversitesi'nden 2020.12.117 karar numaralı etik kurul kararı ve Nevşehir İl Milli Eğitim Müdürlüğü'nden 49405861-44-E.8338244 sayılı araştırma izni alınmıştır.

\section{Bulgular}

Bu bölümde bulgular araştırma soruları çerçevesinde sıra ile sunulmuştur. Bunlar; yüz yüze eğitim ile uzaktan eğitim sürecindeki aile katılım çalışmalarının farklılaşıp farklılaşmamasına ilişkin bulgular, ailelerin uzaktan eğitim sürecine katılıma durumuna ilişkin bulgular, öğretmenlerin uzaktan eğitim sürecinde kullandıkları iletişim kanallarına ilişkin bulgular, öğretmenlerin uzaktan eğitim sürecinde kullandıkları iletişim kanallarını kullanma amaçlarına ilişkin bulgular, uzaktan eğitim sürecine katılan aileler ve katılım gerekçelerine ilişkin bulgular, öğretmenlerin uzaktan eğitim sürecinde karşılaştıkları sorunlara ilişkin bulgular ve uzaktan eğitim sürecinde 
aile katılımının arttırılabilmesi ve verimli hale getirilebilmesi için önerilere ilişkin bulgular şeklinde sıralanmıştır. Bulgular sunulurken frekanslardan yararlanılmıştır.

\section{Yüz Yüze Eğitim İle Uzaktan Ĕ̆itim Sürecindeki Aile Katılım Çalışmalarn- nın Farklılaşıp Farklılaşmamasına İlişkin Bulgular}

Yapılan çalışmada yüz yüze eğitim ile uzaktan eğitim sürecindeki aile katılım çalışmalarının farklılaşmadığını belirten iki öğretmen olurken farklılaştığını ifade eden 24 öğretmen olmuştur. Uzaktan eğitim sürecindeki aile katılım çalışmalarının farklılaşmasına ilişkin ortaya çıkan kategori ve kodlar Tablo 2' de sunulmuştur.

Tablo 2. Uzaktan eğitim sürecindeki aile katılım çalışmalarının farklılaşmama durumu

\begin{tabular}{ll}
\hline Kategoriler & Kodlar \\
\hline Olumlu yönde farklılaşma $(\mathrm{n}=11)$ & Aile katılımının artması \\
& Ailenin sorumluluğun artması \\
\hline Olumsuz yönde farklılaşma $(\mathrm{n}=8)$ & Aile ile iletişim sorunları \\
& Aileden geri bildirim alamama \\
\hline Farklılaşan uygulamalar $(\mathrm{n}=5)$ & Evde yapılabilecek etkinlikleri kullanma \\
& Basit ve ilgi çekici etkinlikleri kullanma \\
\hline
\end{tabular}

Tablo 2 incelendiğinde öğretmenler uzaktan eğitim sürecindeki aile katılım çalışmalarındaki farklılıkları belirtirken aile katılım çalışmalarının olumlu ve olumsuz yöndeki farklılıklarına ve farklılaşan uygulamalara ilişkin görüş belirtmişlerdir. Olumlu yönde farklılaşma kategorisinde aile katılımının artması ve ailenin sorumluluğun artması ön plana çıkmıştır. Aileler bu süreçte daha fazla sorumluluk almış ve çocukların eğitim sürecine daha fazla katılmışlardır. Örneğin, 'Ailelerin katılımı daha fazla oldu. Çoğunlukla onlar yürüttüler (12)'. Olumsuz yönde farklılaşma kategorisi aile ile iletişim sorunları ve aileden geri bildirim alamama kodlarından oluşmaktadır. Öğretmenler uzaktan eğitim sürecinde ailelerle iletişim kurmada sıkıntı yaşamışlardır. Ayrıca evde yapılan çalışmalarla ilgili geri dönüt alamama da öğretmenlerin yaşadığ 1 olumsuzluklar olarak ortaya çıkmıştır. Örneğin, 'Yüz yüze eğitim gibi değil, iletişim zor (21)'. Uygulama boyutunda farklılaşma kategorisinde ise aile ile birlikte evde yapılabilecek etkinlik belirleme ve etkinliklerin ilgi çekici ve basit olmasına dikkat etme ortaya çıkmıştır. Öğretmenler uzaktan eğitim sürecinde uygulanan etkinliklerde değişiklik ya- 
parak ailelerin çocuklarla birlikte yapabilecekleri etkinlikler seçmeye çalışmışlardır. Örneğin, 'Ailelerin evde uygulayabilecekleri etkinliklere yer verildi (7)'.

\section{Ailelerin Uzaktan Ĕ̆itim Sürecine Katılma Durumuna İlişkin Bulgular}

Ailelerin uzaktan eğitim sürecine katılımı ile ilgili öğretmenlerin görüşleri analiz edildiğinde ortaya çıkan kategori ve kodlar Tablo 3'te sunulmuştur.

Tablo 3. Ailelerin uzaktan eğitim sürecine katılım durumu

\begin{tabular}{ll}
\hline Kategoriler & Kodlar \\
\hline Aktif katılım sağlama $(\mathrm{n}=13)$ & Katılım iyi olduğunu düşünme \\
& Ailelerin ilgili olduğunu düşünme \\
& Ailelerin performansından memnun olma \\
& Katılımın yoğun olduğunu düşünme \\
\hline Aktif katılım sağlamama $(\mathrm{n}=11)$ & Aile katılımını yetersiz bulma \\
& Etkili katıllımın olmadığını düşünme \\
& İstenilen seviyede katılımın olmaması \\
\hline Katılımın aileye göre & İgili velilerin katılması \\
değişkenlik göstermesi $(\mathrm{n}=3)$ & Bazı istekli ailelerin katıllması \\
\hline
\end{tabular}

Tablo 3 incelendiğinde aktif katılım sağlama, aktif katılım sağlamama ve katılımın aileye göre değişkenlik göstermesi olmak üzere üç kategori ortaya çıkmıştır. Aktif katılımın olduğunu ifade eden öğretmenler; katılımın iyi ve yoğun olduğunu, ailelerin ilgili olduğunu ve ailelerin performanslardan memnuniyetlerini belirtmişlerdir. Örneğin, 'Zorlanmalarma rağmen güzel emek verdiklerini düşünüyorum (27)'. Aktif katılımın olmadığını belirten öğretmenler; aile katılımını yetersiz bulduklarını, etkili katılımın olmadığını ve katılımın istenilen seviyede olmadığını dile getirmişlerdir. Örneğin, 'Ailelerin uzaktan eğitim sürecine katılımı az sayıda ve etkinliklere ilgi azdı (25)'. Katıllmın aileye göre değişkenlik gösterdiğini belirten öğretmenler ise; ilgili ve istekli ailelerin katılım sağladığını ifade etmişlerdir. Örneğin, 'Katılan istekli olan veliler olduğu gibi, bu süreçte hiç katılmayan velilerde oldu (8)'.

\section{Öğretmenlerin Uzaktan Eğitim Sürecinde Kullandıkları İletişim Kanallarına İlişkin Bulgular}

Öğretmenlerin uzaktan eğitim sürecinde kullandıkları iletişim kanallarına ait frekans bilgileri Tablo 4 'te sunulmuştur. 
Tablo 4. Öğretmenlerin uzaktan eğitim sürecinde kullandıklan iletişim kanallan

\begin{tabular}{ll}
\hline Illetişim Kanalı & $\mathbf{N}$ \\
\hline WhatsApp mesaj uygulaması & $(\mathrm{n}=21)$ \\
Telefon görüşmesi & $(\mathrm{n}=13)$ \\
EBA platformu & $(\mathrm{n}=7)$ \\
Telefon/WhatsApp üzerinden görüntülü görüşme & $(\mathrm{n}=4)$ \\
SMS & $(\mathrm{n}=3)$ \\
Sosyal medya & $(\mathrm{n}=2)$ \\
E-mail & $(\mathrm{n}=2)$ \\
\hline
\end{tabular}

Tablo 4 incelendiğinde öğretmenlerin çoğunun WhatsApp mesaj uygulamasını kullandıkları görülmektedir. WhatsApp mesaj uygulamasını sırasiyla telefon görüşmesi, EBA platformu, telefon/WhatsApp üzerinden görüntülü görüşme, sms, sosyal medya ve e-mail takip etmiştir.

\section{Öğretmenlerin Uzaktan Eğitim Sürecinde Aileler ile İletişime Geçme Amaçlarına İlişkin Bulgular}

Öğretmenlerin uzaktan eğitim sürecinde aileler ile iletişime geçme amaçlarına ilişkin ortaya çıkan kategori ve kodlar Tablo 5'te sunulmuştur.

Tablo 5. Öğretmenlerin uzaktan eğitim sürecinde aileler ile iletişime geçme amaçlar

\begin{tabular}{ll}
\hline Kategoriler & Kodlar \\
\hline Eğitim ve öğretim $(\mathrm{n}=25)$ & Eğitim faaliyetlerini yürütme \\
& Gelişimi destekleme \\
& Etkinlik/Ödev paylaşımı \\
& Etkinlik takibi \\
& Etkinliğe katııı sağlama \\
& Kitap önerileri paylaşma \\
\hline İletişim $(\mathrm{n}=6)$ & Aile ile konuşma \\
& Aile ile mesajlaşma \\
\hline Destek $(\mathrm{n}=6)$ & Psikolojik destek \\
\hline Bilgilendirme $(\mathrm{n}=5)$ & Rehberlik \\
\hline
\end{tabular}

Tablo 5 incelendiğinde öğretmenlerin; eğitim öğretim, iletişim, destek ve bilgilendirme amaçlı ailelerle iletişime geçtikleri görülmektedir. Eğitim öğretim kategorisi; eğitim faaliyetlerini yürütme, gelişimi destekleme, etkinlik paylaşımı, etkinlik takibi, etkinliğe katılımı sağlama ve kitap önerisinde bulunma içeriklerinden oluşmaktadır. Örneğin, 'Günlük etkinlik gönderimi ve uygulamaların geri bildirimi için aynı zamanda değerlendirme yapmak için kullandım (12)'. İletişim kategorisi; eğitim öğretim faaliyetleri dışında aileler ile konuşma ve mesajlaşma içeriklerine sahiptir. Örneğin, 'Aile ve çocukla ko- 
nuşma amaçl kullandım (9)'. Destek kategorisi; psikolojik destek ve rehberlik içeriklerinden oluşmaktadır. Öğretmenler uzaktan eğitim sürecinin ve pandeminin olumsuzluklarını önlemek için ailelere destek amaçlı iletişime geçmişlerdir. Örneğin, 'Çocuklarm pandemi sürecindeki psikolojik durumu ve uzaktan eğitim ile ilgili görüşme amact ile kullamıldı (25)'. Bilgilendirme kategorisi ise süreçte gerçekleştirilecek uygulamalar hakkında bilgilendirme ve duyuruları kapsamaktadır. Örneğin, 'Uzaktan eğitim sürecinde okul yönetimi tarafindan iletilmesi gereken masajları paylaşmak için kullandım (28).'

\section{Uzaktan Eğitim Sürecine Katılan Aile Bireyleri ve Katılım Gerekçelerine İlişkin Bulgular}

Uzaktan eğitim sürecine aile bireylerinden hangisinin katıldığı ile ilgili öğretmenlerin görüşleri analiz edildiğinde 22 öğretmen annelerin katıldığını belirtmişlerdir. Babaların tek başına katılım gösterdiğini ifade eden öğretmen olmazken anne ve babanın her ikisinin katılım gösterdiğini belirten dört öğretmen olmuştur. Annelerin uzaktan eğitime katılım gerekçesine ilişkin ortaya çıkan frekans dağılımı Tablo 6' da verilmiştir.

Tablo 6. Annelerin uzaktan eğitim sürecine katılım gerekçeleri

\begin{tabular}{lc}
\hline Gerekçe & $\mathbf{N}$ \\
\hline Babanın çalışması/Annenin ev hanımı olması & $(\mathrm{n}=7)$ \\
Annelerin evde bulunması & $(\mathrm{n}=4)$ \\
Öğretmenin kadın olması & $(\mathrm{n}=2)$ \\
Annelerin çocukların eğitiminde aktif olması & $(\mathrm{n}=1)$ \\
Annenin eşi ile boşanmışolması & $(\mathrm{n}=1)$ \\
\hline
\end{tabular}

Tablo 6 incelendiğinde uzaktan eğitim sürecine annelerin katılım göstermelerinin en önemli gerekçesi babanın çalışması veya annenin ev hanımı olmasıdır. Bunu sırasıyla annelerin evde bulunması, öğretmenin kadın olması, çocuğun eğitiminde annenin aktif olması ve annenin eşi ile boşanmış olması gelmektedir. Örneğin, 'Babalar işleri dolasıyla katılamadı (11)'. 'Anneler evde kaldıklar için daha fazla zaman ayırdılar (35)'. 'Bayan olduğum için (3) (18)'.

\section{Öğretmenlerin Uzaktan Eğitim Sürecinde Karşılaştıklarn Sorunlara İlişkin Bulgular}

Öğretmenlerin uzaktan eğitim sürecinde karşılaştıkları sorunlara ilişkin ortaya çıan kategori ve kodlar Tablo 7'de sunulmuştur. 
Tablo 7. Öğretmenlerin uzaktan eğitim sürecinde karşılaştıkları sorunlar

\begin{tabular}{ll}
\hline Kategoriler & \multicolumn{1}{c}{ Kodlar } \\
\hline Aile ile ilgili sorunlar $(\mathrm{n}=18)$ & Aile ile iletişim kuramama \\
& Ailenin teknolojik gereçlerin yetersiz olması \\
& Aile katılımının yetersiz olması \\
& Ailelerin ilgisiz tutumları \\
\hline Çocuklarla ilgili sorunlar $(\mathrm{n}=9)$ & Çocuklarla iletişim kuramama \\
& Çocuklarla etkileşimin olmaması \\
& Çocukları zorlayamama \\
\hline İnternet ve sistemsel sorunlar $(\mathrm{n}=5)$ & İnternet bağlantı sorunu \\
& EBA sisteminin yetersizliği \\
\hline
\end{tabular}

Tablo 7 incelendiğinde; ailelerle ilgili sorunlar, çocuklarla ilgili sorunlar ve internet ve sistemsel sorunlar olmak üzere üç kategori ortaya çıkmıştır. Ailelerle ilgili sorunlarda; ailelerle iletişim kurulamaması, ailelerin yeterli teknolojik araç-gereçlere sahip olamaması, aile katılımının yetersiz olması ve ailelerin ilgisiz tutumları ön plana çıkmıştır. Örneğin, 'İnterneti olmayanların olması da katılımı engelledi. Ayrıca bu sürede pek çok öğrencinin internet kullanmak durumunda olmasl, ayn evde yaşayan abi, abla birlikte bilgisayar veya cep telefonunu kullanmak durumu herkes için yeterli olamad. Özellikle orta halli veliler için zorlayıcı olmuştur (24)'. Çocuklarla ilgili sorunlarda öğretmenler daha çok çocuklarla iletişim kuramamayı ve çocuklarla etkileşimin olmamasını ifade etmişlerdir. Öğretmenler ayrıca uzaktan eğitim sürecinde çocukları zorlayamamayı da sorun olarak görmüşlerdir. Örneğin, 'Çocuklarla bire bir iletişim kuramamak. Çocukların yaşıtlarıla bir arada olmamasından kaynaklanan akran etkileşiminin olmaması (28)'. İnternet ve sistemsel sorunlarda öğretmenler, internet bağlantısında ve EBA sistemini kullanmada yaşanan sorunları dile getirmişlerdir. Örneğin, 'Eba ya etkinlik yükleyememe sorunu yaşadım (31)'.

\section{Uzaktan Ĕ̆itim Sürecinde Aile Katılımının Arttırılması ve Verimli Hale Getirilmesi İçin Önerilere İlişkin Bulgular}

Öğretmenlerin uzaktan eğitim sürecinde aile katılımının arttırılması ve verimli hale getirilmesi için önerilerine ilişkin ortaya çıan kategori ve kodlar Tablo 8'de sunulmuştur. 
Tablo 8. Uzaktan eğitim sürecinde aile katılımının arttırılması ve verimli hale getirilmesi için öneriler

\begin{tabular}{ll}
\hline Kategoriler & \multicolumn{1}{c}{ Kodlar } \\
\hline Ailelere yönelik öneriler (17) & Aileye eğitim vermek \\
& Aile ile olumlu iletişim sağlamak \\
& Aileyi eğitime zorunlu katmak \\
& Aileyi teşvik etmek \\
\hline Sistemsel yapıya yönelik öneriler (n=7) & İternet sorununu çözmek \\
& Sistem altyapısını düzeltmek \\
& Sisteme yeterli kaynak yüklemek \\
\hline Çocuklara yönelik öneriler (n=5) & Evde uygulanabilir etkinlik seçmek \\
& İlgi ve dikkat çekici etkinlik seçmek \\
& Aile ile birlikte yapilabilecek etkinlik seçmek \\
\hline
\end{tabular}

Tablo 8 incelendiğinde; ailelere, sistemsel yapıya ve çocuklara yönelik öneriler olmak üzere üç kategori ortaya çıkmıştır. Ailelere yönelik önerilerde; aile eğitiminin verilmesi, ailelerle olumlu iletişimin sağlanması, ailenin eğitime zorunlu katılımın sağlanması ve ailenin teşvik edilmesi ön plana çıkmaktadır. Örneğin, 'Önce ailenin yapılacak etkinlik kazanımları ve sonuçları hakkında bilgilendirilmesi verimi artıracaktır diye düşünüyorum (27)'. Sistemsel öneriler; internet sorununun çözümü, sistem altyapısının düzenlenmesi ve sistemde yeterli kaynakların olması içeriklerinden oluşmaktadır. Örneğin, 'Başta Öğretmenin ulaşabileceği, çocuklarla canlı iletişim kurabileceğgi dijital çoklu ortamlarm güvenli ve kolay hale getirilmesi (30)'. Çocuklara yönelik önerilerde ise; evde uygulanabilir etkinlik seçme, etkinliklerin ilgi ve dikkat çekici olmasına dikkat etme ve etkinliklerin aile ile birlikte yapılabilecek olanlarını seçme ön plana çıkmaktadır. Örneğin, 'Etkinlikler ailelerin çocuklarıla eğlenerek yapabileceği ş̧ekilde düşünülmeli (31)'.

\section{Tartışma ve Sonuç}

Okul öncesi öğretmenlerinin uzaktan eğitim sürecinde uyguladıkları aile katılım çalışmalarını incelemek amacıyla gerçekleştirilen bu çalışmada tartışma, bulgular dikkate alınarak sıra ile sunulmuştur.

Yapılan çalışmada yüz yüze eğitim ile uzaktan eğitim sürecindeki aile katılım çalışmalarının farklılaşmadığını belirten iki öğretmen olurken farklılaştı̆̆ın ifade eden 24 öğretmen olmuştur. Uzaktan eğitim ile yüz yüze eğitimde; öğrenci ve öğretmenin birbirlerinden ayrı olması, öğretmen ile öğrencinin kitle iletişim araçları ve ortamları ile bir araya gelmesi ve iletişimbilişim teknolojilerini eğitim-öğretim amaçlı kullanma gibi farklılıklar bu- 
lunmaktadır (Kaya, 2002, s. 13). Benzer şekilde uzaktan eğitim sürecinde okul öncesi öğretmenlerinin gerçekleştirdikleri aile katılım çalışmalarında da farklılıklar ortaya çıkmıştır. Zira ailelerle farklı bir eğitim-öğretim süreci gerçekleştirilmekte ve bu süreçte bir takım değişikliklerin olması doğal görünmektedir. Olumlu yönde farklılaşmada aile katılımının ve ailenin sorumluluğun artması ön plana çıkmıştır. Okul öncesi eğitimde aile katılımının önemi bilinmekte ve ailenin de sorumluluk alması beklenmektedir (MEB, 2013, s. 10). Uzaktan eğitim sürecinde aile katılımının önemi daha da artmaktadır. Bu durumun ortaya çıkmasında çocukların gelişimsel özelliklerinden kaynaklı tek başlarına uzaktan eğitim sürecine dâhil olamayacakları ve ailenin desteğine ihtiyaç duymaları ile açılanabilir. İletişim ve etkileşim aile katılım çalışmalarında önemli bir boyutu oluşturmaktadır. Ancak uzaktan eğitim sürecinde ailelerle iletişim ve etkileşim yüz yüze eğitimde olduğu gibi istenilen düzeyde olamamıştır. Bu durum aile katılım çalışmalarının etkililiğini de azaltmıştır. Öğretmenler ayrıca uygulama boyutunda da değişikliğin olduğunu belirterek ailelerin çocuklarla birlikte yapabilecekleri etkinliklerin yapılmasına öncelik vermişlerdir. Bu süreçte aileler bir nevi öğretmen rolünü üstlenmişler ve öğretmenlerin uygulamalarında değişikliğe yol açmışlardır.

Araştırma bulgularında ailelerin yaklaşık yarısının uzaktan eğitim sürecine aktif katıldığı görülmektedir. Hapsari, Sugito ve Fauziah (2020)'ın ve Novianti ve Garzia (2020)'nın çalışmalarında ailelerin çoğunun uzaktan eğitim sürecinde çocukların evde eğitim etkinliğine aktif olarak katıldığ ortaya çıkmıştır. Araştırma bulguları yapılan diğer çalışmalarla kıyaslandığında aile katılımının çok daha az seviyede olduğu sonucunu doğurmaktadır. Bu durum okul öncesi eğitimin hedeflerine ulaşmasında bir sorun olarak değerlendirilebilir. Morrison (2006)'a göre aile katılımı, okul öncesi eğitim programının başarısını arttırmada çok önemli bir işleve sahiptir (Morrison, 2006'dan aktaran: Günay Bilaloğlu, 2014, s. 3) Dolayısıyla öğretmenler hem okul öncesi eğitimde başarı elde etmek hem de çocukların başarısını arttırmak için ailelerin öğrenme etkinliklerine katılımını sağlamalıdırlar. Özellikle uzaktan eğitim sürecinde aile katılımının önemi daha da artmaktadir.

Uzaktan eğitim sürecinde öğretmenlerin çoğunun WhatsApp mesaj uygulamasını kullanarak aileler ile iletişime geçtikleri görülmektedir. WhatsApp mesaj uygulamasını sırasıyla telefon ve EBA uygulaması takip etmiş- 
tir. Benzer bulgu Novianti ve Garzia (2020)'nın çalışmasında da ortaya çıkmış, öğretmenler en çok WhatsApp mesaj uygulaması ile iletişim sağlamışlardır. Balcı ve Tezel Şahin (2018)'in çalışmalarında da okul öncesi öğretmenleri ailelerle iletişimde WhatsApp gruplarını tercih etmişlerdir. MEB (2013)'e göre; telefon görüşmeleri, kısa ileti hizmetleri, kitapçıklar, görsel işitsel kayıtlar, fotoğraflar, duyuru panoları, bültenler, haber mektupları, yazışmalar/iletişim defterleri, gelişim dosyaları (portfolyo), toplantılar, okul ziyaretleri, geliş gidiş zamanları, internet temelli uygulamalar ve dilek kutuları aileler ile etkili iletişim yöntemleridir. Ancak uzaktan eğitim sürecinde diğer iletişim yöntemlerine göre telefon görüşmeleri ve internet temelli uygulamaların kullanımı ön plana çıkmıştır. Çünkü uzaktan eğitimde internet ve teknoloji kullanımı sürecin temel bileşenlerindendir. İnternet aynı zamanda dünyada kullanılan yaygın iletişim araçlarındandır (Akbulut, Şahin ve Esen, 2020, s.33).

Öğretmenler uzaktan eğitim sürecinde daha çok eğitim-öğretim süreçleri için ailelerle iletişime geçmişlerdir. Novianti ve Garzia (2020)'nun çalışmasinda da öğretmenler uzaktan eğitim sürecinde WhatsApp mesaj uygulaması ile ödevler vermişlerdir. Balcı ve Tezel Şahin (2018)'in çalışmalarında da okul öncesi öğretmenleri yüz yüze eğitim sürecinde daha çok duyuru yapmak için WhatsApp mesaj uygulamasını kullanmışlardır. Uzaktan eğitimde eğitim öğretim süreci teknolojik araç ve gereçlerle gerçekleşmektedir. Öğretmenler de teknolojinin bir ürünü olan WhatsApp uygulamasını daha çok eğitim öğretim faaliyetlerini yürütmek için kullanmışlardır. Bulgularda ortaya çıkan diğer bir durum öğretmenlerin destek amaçlı ailelerle iletişime geçmeleridir. Ailelerin ve çocukların salgın sürecinde öğretmenlerin desteklerini almaları önem taşımaktadır. Bu durum öğretmenlerin sadece eğitim öğretim amaçlı ailelerle iletişime geçmeyip her türlü süreçte ailenin yanında olduğu hissini vermesi açısında da önemli görülmektedir.

Uzaktan eğitim sürecine annelerin katılım gösterdiğini ifade eden 22 öğretmen olmuştur. Babaların tek başına katılım gösterdiğini ifade eden öğretmen olmazken anne ve babanın her ikisinin katılım gösterdiğini belirten dört öğretmen olmuştur. Bu bulguya benzer çalışmalar bulunmaktadır. Örneğin Hapsari vd. (2020)'nin ve Novianti ve Garzia (2020)'nın çalışmasında da çocukların evde öğrenme etkinliğine eşlik eden annelerin çoğunlukta olduğu ortaya çıkmıştır. Özyürek ve Tezel Şahin (2005)'e göre de çocukların eğitiminden anneler sorumlu olarak görülmüştür. Ayrıca Finley, 
Mira ve Schwartz (2008)'e göre de anneler babalara göre daha fazla ifade etme becerilerine sahiptirler. Bu durum okul öncesi dönem çocuklarının eğitiminde ana karakter olarak annelerin belirgin olduğunu göstermektedir. Babaların işleri dolayısıyla yorgun olmaları nedeniyle evde çocuğunun eğitimine katılamama durumu söz konusu olmaktadır (Hornby ve Lafaele, 2011, s. 41). Ancak babanın da çocukların eğitim süreçlerine dahil olması gerekmektedir. Çünkü babaların çocukların eğitimine katılımları çocuğun gelişimini olumlu yönde etkilemektedir. Okul öncesi dönemde aile katılım çalışmalarına babaların katılım sağladığı durumlarda çocukların; okul performanslarının daha iyi olduğu, özgüvenlerinin daha yüksek olduğu, sağlıklı akran etkileşimine sahip oldukları, sağlıklı cinsiyet rol gelişiminin olduğu ve akademik başarılarının yüksek olduğu ortaya çıkmıştır (Deretarla Gül, 2013, s. 228-229). Uzaktan eğitim sürecine annelerin katılım göstermelerinin en önemli gerekçesi babanın çalışması veya annenin evde olması gelmektedir. Her ne kadar çalışan anneler olsa da genellikle ailenin gelirini sağlamakla yükümlü kişiler olarak babalar bilinmektedir. Han ve Jun (2013)'un çalışmasında da benzer bulgular ortaya çımış ve ailenin gelir kaynağı olarak daha çok babalar görülmüş̧ür. Babaların bir işte çalışıyor olması ve annelerin ev hanımı olmaları çocukla ilgilenecek kişinin anne olmasına yol açmaktadır.

Öğretmenler uzaktan eğitim sürecinde; ailelerle ilgili, çocuklarla ilgili ve internet ve sistemsel yapı ile ilgili sorunlar yaşamışlardır. Benzer şekilde; Türkçe öğretmenleri (Bayburtlu, 2020, s. 139-140), Sınıf öğretmenleri, Rehber öğretmenler, Beden Eğitimi öğretmenleri, Matematik öğretmenleri, İngilizce öğretmenleri (Akyavuz ve Çakın, 2020, s. 169) ve Fen Bilgisi öğretmenleri (Bakioğlu ve Çevik, 2020, s. 118) salgın döneminde uygulanan uzaktan eğitim sürecinde sorunlarla karşılaşmışlardır. Öğretmenlerin ilk defa uzaktan eğitime başlamaları ile bu süreçte sorunlar yaşamaları normal karşılanabilir. Çünkü farklı bir eğitim öğretim süreci yaşanmakta ve farklı uygulamalar gün yüzüne çıkmaktadır. Bu durum bir takım belirsizlikleri ve yeni bir sürece uyum sağlamayı da gerektirmektedir.

Aileden kaynaklı sorunlarda; aile ile iletişim kuramama, ailede teknolojik araç gereçlerin yetersiz olması, aile katılımının yetersiz olması ve ailelerin ilgisiz tutumları ön plana çıkmıştır. Öğretmenler uzaktan eğitim sürecinde aileler ile iletişim sorunları yaşadıklarını belirtmişlerdir. Benzer bulgu Akyavuz ve Çakın (2020)'ın ve Foti (2020)'nin çalışmasında da ortaya çımış ve 
uzaktan eğitim sürecinde öğretmenler ailelerle iletişim kurmada sorun yaşamışlardır. Aile ve öğretmen arasındaki iki yönlü iletişim ile ailelerin ve öğretmenlerin çeşitli durumlarda çocukları eğitmek için birlikte çalışabilmelerinin beklenmesidir. Etkili iletişimin sağlanamadığı bu durumda çocukların eğitimi istenilen düzeyde olamayacaktır. Ailelerin bazılarında uzaktan eğitim sürecini sürdürmek için herhangi bir cihaz veya internet bağlantısı bulunmazken bazılarında birden çok kardeş arasında paylaşılan tek bir cihaz bulunabilmektedir. Araştırma bulguları ile benzer bulgulara sahip araştırmalar bulunmaktadır. Örneğin; Foti (2020)'nin çalışmasında ailelerin bilgisayarlara erişememesi ve eğitim materyali eksikliği, Akyavuz ve Çakın (2020)'ın çalışmasında teknoloji yetersizliği, Bayburtlu (2020)'nun çalışmasında öğrencilerin bilgisayar ve tablet gibi cihazlarının olmayışı ve Bakioğlu ve Çevik (2020)' in çalışmasında öğrencinin bilgisayara erişememesi sorun olarak ortaya çıkmıştır. Bu durum ailenin ekonomik durumuna bağlı bir sonuç olarak ortaya çıkmaktadır. Böyle bir durumda çocukların eğitimden uzak kalmaması için ihtiyaç sahibi ailelere gerekli destek sağlandığında eğitim öğretim süreci daha etkili bir şekilde yürütülecektir. Aile katılımının yetersiz olması kasıtlı olarak katılmama ve engellerden kaynaklı katılamama olarak iki açıdan değerlendirilebilir. Kasıtlı olarak katılım sağlamayan aileler çocukların eğitimi ile ilgili yeterli sorumluluğu almayan veya almak istemeyen ailelerdir. Foti (2020)'nin çalışmasında ailelerin geri bildirimin çok az olduğu veya olmadığı, Akyavuz ve Çakın (2020)'ın çalışmasında ailelerin ilgisiz oldukları ve geri bildirim vermedikleri ve Bayburtlu (2020)'nun çalışmasında ailelerin ilgisiz oldukları sonucuna ulaşılmış ve bu durum uzaktan eğitim sürecinde olumsuzluk olarak ifade edilmiştir. Yapılan araştırmalarda aileler bazı sorunlardan dolayı çocukların eğitimine katılamamışlardır. Örneğin; Akbulut vd. (2020)'nin çalışmasında ailelerin bilgi ve teknoloji becerilerinin yetersizliği nedeniyle, Brown vd. (2020)'nin çalışmasında ailelerin yeterli kapasitede olmaması ve kullanılan eğitim platformu deneyimlerinin olmaması nedeniyle ve Novianti ve Garzia (2020)'nun çalışmasında ailelerin teknolojik cihazları kullanmaya alışkın olmaması nedeniyle uzaktan eğitim sürecinde sorun yaşadıkları saptanmıştır. Sorunlardan dolayı uzaktan eğitim sürecine katılamayan ailelerin sorunları için çözüm üretilebilir. Aile eğitim çalışmaları planlanabilir ve sürece adapte olmaları sağlanabilir. 
Çocuklardan kaynaklı sorunlarda iletişim ve etkileşimin olmaması ön plana çıkmaktadır. Foti (2020)'nin çalışmasında benzer bulgu ortaya çıkmış, öğretmenlerin çoğu öğrencilerle arasındaki etkileşimin olmamasını sorun olarak görmüşlerdir. Okul öncesi dönemde çocukların etkileşim halinde olması önem arz etmektedir. Vygotsky'nin bilişsel gelişim kuramına göre de zihinsel süreçler sosyal etkileşimlerle başlar. Etkileşimli ortam öğrenme için anlamlı bir sosyal bağlam sağlar. Vygotsky'e göre çocukların hem yetişkinlerle hem de diğer çocuklarla işbirliği içinde çalışmaları bilişsel gelişimlerini desteklemektedir. Çocuklar bir başkasıyla konuştuğunda ve iletişim kurduğunda düşünmesindeki aksaklıklar ve boşluklar ortaya çıkar ve düzeltmeye hazır hale gelir (Bodrova ve Leong, 2010, s. 14-17). Uzaktan eğitim sürecinde çocukların hem öğretmeni ile hem de akranları ile sosyal etkileşim imkânları olamamıştır. Bu durum çocukların gelişim sürecini olumsuz etkilemiştir.

İnternet ve sistemsel yapı ile ilgili sorunlarda internet bağlantı sorunları ve EBA sisteminde yaşanan sorunlar ön plana çıkmaktadır. Benzer sorunlar Bayburtlu (2020)'nun, Bakioğlu ve Çevik (2020)'in, Akyavuz ve Çakın (2020)'ın ve Doğan ve Koçak (2020)'ın değişik branştaki öğretmenlerle gerçekleştirdikleri çalışmalarda da ortaya çıkmıştır. Yapılan çalışmaların farklı illerde gerçekleştirildiği göz önünde bulundurulduğunda bu sorunun Türkiye'deki internet bağlantısı ve EBA sisteminden kaynaklandığı sonucunu doğurmaktadır. Çağımızda iletişim aracı olarak yaygın şekilde kullanılan internet uzaktan eğitim sürecinde de önemli bir fonksiyona sahiptir. İnternetin bu denli yüksek kullanım oranına sahip olmasına rağmen ailelerin buna erişimi maalesef istenilen düzeyde olmamaktadır. Bu durum uzaktan eğitimin etkili bir şekilde yürütülmesine de engel olmaktadır. Ayrıca uzaktan eğitim sürecinde EBA sisteminde yaşanan teknik sorunlar uzaktan eğitimin gerçekleşmesini engelleyen bir faktör olarak ortaya çıkmıştır. Bu durum uzaktan eğitimin etkili bir şekilde yürütülmesine de engel olmaktadır.

Uzaktan eğitim sürecinde aile katılımının arttırılabilmesi ve verimli hale getirilebilmesi için öğretmenlerin önerileri analiz edildiğinde; ailelere yönelik önerilerde; aile eğitiminin verilmesi ve ailelerle olumlu iletişimin sağlanması ön plana çıkmaktadır. Günümüzde her konuda yaşanan hızlı değişimler, ailelerin eğitim gereksinimlerinin de farklılaşmasını sağlamaktadır (MEB, 2013, s. 7). Salgın sürecinde de aileler ilk defa uzaktan eğitim süreci ile tanışmışlardır. Bu durum ailelerin uzaktan eğitim sürecinde bir takım sorunlar yaşamasına neden oluştur. Bu durumda ailelere gerekli eğitimin 
verilmesi ve bu sayede etkili bir eğitim sürecinin sağlanması öğretenler tarafından vurgulanan nokta olmuştur. Aynı şekilde etkili iletişim sağlanarak okul ile aile arasındaki kopukluğun önüne geçilebilir ve bu sayede daha etkili bir katılım sağlanabilir. Sistemsel öneriler daha çok internet ve EBA sisteminin olumsuzluklarına yönelik olmuştur. Uzaktan eğitimin gerçekleşmesi için internet elzemdir. Ailelere gerekli internet desteğinin sağlanması daha etkili bir aile katıım çalışmalarının sürmesini sağlamaktadır. Aynı zamanda EBA platformunun da kullanımına yönelik alt yapı oluşturulması gerekmektedir. Çocuklara yönelik önerilerde ise; aileleriyle birlikte evde uygulanabilir etkinlik seçme ön plandadır. Okul öncesi dönemde uzaktan eğitimin aileler kanalıyla gerçekleştiği bilinmektedir. Aile evde öğretmen konumunu alan kişilerdir. Bu durumda ailelerin etkinliği anlayabileceği ve uygulayabileceği türden olması gerekmektedir. Böylece etkili bir süreç ve aile katılımı gerçekleştirilmiş olur.

Okul öncesi öğretmenleri uzaktan eğitim sürecinde zorluklara rağmen aile katılım çalışmalarını gerçekleştirmişlerdir. Okul öncesi öğretmenlerinin uyguladıkları aile katılım çalışmalarının uzaktan eğitim sürecinde farklılaştığı sonucuna ulaşılmıştır. Ailelerin uzaktan eğitim sürecinde aile katılım çalışmalarına yeteri kadar katılmadıkları/katılamadıkları ortaya çıkmışıır. Okul öncesi öğretmenleri uzaktan eğitim sürecinde ailelerle daha çok WhatsApp mesaj uygulaması kanalıyla iletişime geçmişlerdir. Aile bireylerinden en çok annelerin uzaktan eğitim sürecine dâhil olduğu ortaya çıkmıştır. Okul öncesi öğretmenlerinin uzaktan eğitim sürecinde ailelerle, çocuklarla ve sistemsel yapı ile sorunlar yaşadıkları ve bunlara yönelik önerileri olduğu sonucuna ulaşılmıştır.

Bu çalışmada okul öncesi öğretmenlerinin uzaktan eğitim sürecinde uyguladıkları aile katılım çalışmaları araştırılmıştır. Benzer çalışma aileler üzerinden yapılabilir ve ailelerin uzaktan eğitim sürecinde yaşadıkları incelenebilir. Ayrıca okul öncesi öğretmenlerinin uzaktan eğitim sürecinde uyguladıkları eğitim öğretim faaliyetleri incelenebilir. Öğretmenler okul yönetimi ile işbirliği içerisinde aile eğitim faaliyetleri düzenleyebilir. Babaların eğitime katılımına yönelik eğitimler düzenlenebilir. 


\title{
EXTENDED ABSTRACT
}

\section{Investigation Of The Family Participation Activities Which Pre-School Teachers Apply In The Distance Education Process}

\author{
Serhat Gündoğdu \\ Nevşehir Hacı Bektaş Veli University
}

Coronavirus (Covid-19) epidemic has adversely affected the education system in Turkey. Schools were closed on 16 March 2020, Turkey to prevent the spread of the epidemic. After a short preparation, the distance education process was started for all education levels from pre-school to high school on March 23, 2020. During the epidemic period, distance education emerged as a method applied for pre-school education. It is difficult for preschool children to participate in the distance education process independently. Therefore, family participation in the distance education process inevitably comes to light as in normal education. Families are of critical importance to ensure harmony between home and school in the distance education process and to minimize the disadvantages of distance education.

Parents' participation in the education of their children is seen as an important factor in the effectiveness and success of education in the preschool period (Hornby \& Lafaele, 2011, p.37). Family participation, which is defined as parents' taking responsibility in the education of children, playing roles and contributing to the education of children (Ural, 2010 as cited in Aktaş Arnas, 2013, p.55), also increases the gains of the child. Teachers have a great responsibility in family participation activities in pre-school education. The importance that teachers give to family participation also affects the quality of participation (Koçyiğit, 2015, p.142).

In Turkey, there are many studies on family involvement in pre-school education. However, family participation studies should be examined in the distance education processes after the newly encountered COVID. This study aims to examine the family participation studies applied by preschool teachers in the distance education process. 
This study, which aims to examine the family participation studies applied by preschool teachers in the distance education process, was designed with a case study, one of the qualitative research approaches. The study group of the research consisted of 35 preschool teachers working in Nevşehir province. Participants were selected by random sampling method. The data were collected with an interview form prepared with semi-structured interview questions. The interview form consists of open-ended questions about the personal information of the participants and the family participation studies applied by preschool teachers in the distance education process. The data obtained from the interview records were analyzed by content analysis method. By applying the inductive approach in content analysis, the codes were produced directly from the data and categories were created. In the data analysis process, information was exchanged with an academician with a doctorate degree in the field during the category creation process. In order to increase the transferability, quotations from the participants' own expressions were included in the findings. Credibility was achieved by selecting the sample with the purposeful random sampling method. Numbers between 1-35 were given to the participants by using numbers in data analysis within the framework of ethical rules. These numbers are used in the quotations.

In the study, 24 teachers stated that face-to-face education and family participation studies in the distance education process are different. While the teachers stated the differences in family participation studies in the distance education process, they expressed their opinions about the positive and negative differences in family participation studies and the differentiated practices. While some of the families actively participated in the distance education process, some did not. It is seen that most of the teachers use the WhatsApp message application as a communication channel with families. Teachers contacted families for education, communication, support and information purposes. It has been revealed that mothers of the family members are more involved in the distance education process. The most important reason for mothers to participate in the distance education process is that the father is working or the mother is a housewife. In the distance education process, problems with families, problems with children, internet and systemic problems have emerged in family participation studies. Teachers made suggestions for families, systemic structure and children. 
Preschool teachers carried out family participation studies despite the difficulties in the distance education process. It was concluded that the family participation studies applied by preschool teachers differed in the distance education process. It was revealed that the families did not / could not participate in family participation activities sufficiently in the distance education process. Preschool teachers communicated with families mostly via WhatsApp message application during the distance education process. It has been revealed that most of the family members are the mothers involved in the distance education process. It was concluded that pre-school teachers had problems with families, children and systemic structure in the distance education process and had suggestions for them.

In this study, family participation studies applied by preschool teachers in the distance education process were investigated. Similar studies can be done through families and their experiences in the distance education process can be examined. In addition, the educational activities applied by preschool teachers in the distance education process can be examined. Teachers can organize family education activities in cooperation with the school administration. Trainings can be organized for the participation of fathers in education.

\section{Kaynakça / References}

Akbulut, M., Sahin, U. ve Esen, A. C. (2020). More than a virus: how covid 19 infected education in Turkey? Journal of Social Science Education, 19, 30-42.

Aktaş Arnas, Y. (2013). Okul öncesi eğitimde aile katılım. Y. Aktaş Arnas (Ed.), Aile eğitimi ve okul öncesinde aile katıllmı içinde (s. 53-72). Ankara: Vize Yayınları.

Akyavuz, E. K. ve Çakın, M. (2020). Covid-19 salginnnn eğitime etkisi konusunda okul yöneticilerinin görüşleri. Electronic Turkish Studies, 15(4), 723-737.

Avcı, N. (2013). Okul öncesi eğitimde aile katilımı. R. Zembat (Ed.), Okul öncesinde özel öğretim yöntemleri içinde (s. 375-404). Ankara: Anı Yayınları.

Aydoğan, Y. (2010). Okul öncesi eğitim programlarında aile katılımı. T. Güler (Ed.), Anne baba eğitimi içinde (s. 103-140). Ankara: Pegem Akademi Yayıncllk.

Bakioğlu, B. ve Çevik, M. (2020). COVID-19 Pandemisi sürecinde fen bilimleri öğretmenlerinin uzaktan eğitime ilişkin görüşleri. Electronic Turkish Studies, 15(4), 109-129. 
Balcı, A. ve Şahin, F. T. (2018). Öğretmen-aile iletişiminde whatsapp uygulamasının kullanımı. Gazi Üniversitesi Gazi Eğitim Fakültesi Dergisi, 38(2), 749-776.

Balıkçığlu, N., Çınar Öz, D. ve Işın, N. N. (2019). Üniversite öğrencilerinin uzaktan eğitim derslerindeki memnuniyet araştırması: Aşık Veysel Meslek Yüksekokulu örneği. Cumhuriyet Üniversitesi İktisadi ve İdari Bilimler Dergisi, 20(1), 462-473.

Baltacı, A. (2018). Nitel araştırmalarda örnekleme yöntemleri ve örnek hacmi sorunsalı üzerine kavramsal bir inceleme. Bitlis Eren Üniversitesi Sosyal Bilimler Enstitüsü Dergisi, 7(1), 231-274.

Bayburtlu, Y. S. (2020). Covid-19 Pandemi dönemi uzaktan eğitim sürecinde öğretmen görüşlerine göre türkçe eğitimi. Electronic Turkish Studies, 15(4).131-151.

Bodrova, E. ve Leong, D. J. (2010). Zihnin araçlan-erken çocukluk eğitiminde vygotsky yaklaşımı. (T. Güler, F. Şahin, A. Yılmaz ve E. Kalkan, Çev.). Ankara: Anı Yayıncilik.

Brown, N., te Riele, K., Shelley, B. ve Woodroffe, J. (2020). Learning at home during covid19: effects on vulnerable young Australians. 10.10 .2020 tarihinde https://icponline.org/wp-content/uploads/2020/05/L-at-Hrapidresponsereport-30April2020-updated.pdf adresinden erişilmiştir

Creswell, J. W. (2009). Qualitative inquiry and research design: choosing among five traditions. London: Sage.

Çelenk, S. (2003). Okul başarısının ön koşulu: okul aile dayanışması. İlköğretim Online, 2(2), 28-34.

Del Bono, E., Francesconi, M., Kelly, Y. ve Sacker, A. (2016). Early maternal time investment and early child outcomes. Economic Journal 126, 96-135.

Deretarla Gül, E. (2013). Okul öncesi eğitimde babaların katılımını sağlama. Y. Aktaş Arnas (Ed.), Aile eŏitimi ve okul öncesinde aile katılımı içinde (s. 223-237). Ankara: Vize Yayınları.

Doğan, S. ve Koçak, E. (2020). EBA Sistemi bağlamında uzaktan eğitim faaliyetleri üzerine bir inceleme. Ekonomi ve Sosyal Araştırmalar Dergisi, 7(14), 110-124.

Ekinci Vural, D. (2006). Okul öncesi programlarmndaki duyuşsal ve sosyal becerilere yönelik hedeflere uygun olarak hazırlanan aile katılıml sosyal beceri eğitimi programının çocuklarda sosyal becerilerin gelişimine etkisi. Yayımlanmamış yüksek lisans tezi. Dokuz Eylül Üniversitesi, İzmir.

Finley, G. E., Mira, S. D. ve Schwartz, S. J. (2008). Perceived paternal and maternal involvement: factor structures, mean differences, and parental roles. $F a$ therng-Harrman, 6(1), 62-82. 
Foti, P. (2020). Research in distance learning in greek kındergarten schools during the pandemic of covid-19: possibilities, dilemmas, limitations. European Journal of Open Education and E-learning Studies, 5(1), 19-40.

Günay Bilaloğlu, R. (2014). Okul öncesi eğitimde aile katılımı etkinliklerinin uygulanmasında karşılaşılan sorunlar ve aile katılımı etkinliklerinin dil-matematik becerilerinin geliştirilmesine etkisi. Yayımlanmamış doktora tezi. Çukurova Üniversitesi, Adana.

Han, Y. S. ve Jun, W. P. (2013). Parental involvement in child's development: father vs. mother. Open Journal of Medical Psychology, 2, 1-6.

Hapsari, S. M., Sugito, S. ve Fauziah, P. Y. (2020). Parent's involvement in early childhood education during the covid-19 pandemic period. Jurnal Pendidikan Progresif, 10(2), 298-311.

Hornby, G. ve Lafaele, R. (2011). Barriers to parental involvement in education: an explanatory model. Educational review, 63(1), 37-52.

Kaya, Z. (2002). Uzaktan eğitim. Ankara: Pegem A Yayıncılık.

Koçyiğit, S. (2015). Family involvement in preschool education: rationale, problems and solutions for the participants. Educational Sciences: Theory ve Practice, 15(1). 141-157.

MEB, (2013). Okul öncesi eğitim program ile bütünleştirilmiş aile destek eğitim programı. Ankara: T.C. Millî Eğitim Bakanlı̆̆ı, Temel Eğitim Genel Müdürlüğü.

Merriam, S. B. (2013). Nitel araştırma: desen ve uygulama için bir rehber. (S. Turan, Çev.). Ankara: Nobel Yayınları.

Novianti, R. ve Garzia, M. (2020). Parental engagement in children's online learning during covid-19 pandemic. Journal Of Teaching And Learning In Elementary Education, 3(2), 117-131.

Özer, M. (2020). Türkiye' de COVID-19 salgını sürecinde milli eğitim bakanlığı tarafından atılan politika adımları. Kastamonu Education Journal, 28(3), 1124-1129.

Özyürek, A. ve Tezel Şahin, F. (2005). 5-6 yaş grubunda çocuğu olan ebeveynlerin tutumlarının incelenmesi. Gazi Eğitim Fakültesi Dergisi, 25(2), 19-34.

Sooter, T. (2013). Early childhood education in nigeria: issues and problems. Journal of Educational and Social Research, 3, 173-179.

Wilder, S. (2014). Effects of parental involvement on academic achievement: a metasynthesis. Educational Review, 66(3), 377-397.

Yaşar Ekici, F. (2017). Okul öncesi eğitim kurumlarındaki aile katılım çalışmalarına katılan ve katılmayan ailelerin çocuklarının sosyal beceri ve problem davranışları arasındaki ilişki. Hitit Üniversitesi Sosyal Bilimler Enstitüsü Dergisi, 10(1), 543-562. 
Yıldırım, A. ve Şimşek, H. (2005). Sosyal bilimlerde nitel araştırma yöntemleri. Ankara: Seçkin Yayıncllı.

\section{Kaynakça Bilgisi / Citation Information}

Gündoğdu, S. (2021). Okul öncesi öğretmenlerinin uzaktan eğitim sürecinde uyguladıkları aile katılım çalışmalarının incelenmesi. OPUS-Uluslararası Toplum Araştırmaları Dergisi, 17(35), 1849-1874. DOI: 10.26466/opus.827530 